Article

\title{
Experimental Investigation of Methane Generation in the Presence of Surface and Un-Surface Nanoparticles of Iron Oxide
}

\author{
Asim Ali ${ }^{1}$, Hareef Ahmed Keerio ${ }^{2,3, *} \mathbb{C}$, Sallahuddin Panhwar ${ }^{4}$ and Muhammad Zeshan Ahad ${ }^{5}$ \\ 1 Department of Civil Engineering Technology, Benazir Bhutto Shaheed University of Technology \& Skill \\ Development, Khairpur 66020, Pakistan; asimali@inu.edu.pk \\ 2 Department of Civil and Environmental Engineering, Hanyang University, Seoul 04763, Korea \\ 3 Department of Environmental Engineering, Quaid E Awam University of Engineering Science and \\ Technology, Nawabshah 67450, Pakistan \\ 4 Department of Civil Engineering, Balochistan University of Engineering and Technology, \\ Khuzdar 98100, Pakistan; panhwarsallahuddin@yahoo.com \\ 5 Department of Civil Engineering, Iqra National University, Peshawar 25100, Pakistan; \\ muhammadahad81@inu.edu.pk \\ * Correspondence: hareefkeerio@hanyang.ac.kr
}

\section{check for}

updates

Citation: Ali, A.; Keerio, H.A.;

Panhwar, S.; Ahad, M.Z

Experimental Investigation of

Methane Generation in the Presence

of Surface and Un-Surface

Nanoparticles of Iron Oxide.

AgriEngineering 2022, 4, 134-140.

https://doi.org/10.3390/

agriengineering 4010009

Academic Editor: Katarzyna

Januszewicz

Received: 7 December 2021

Accepted: 2 February 2022

Published: 8 February 2022

Publisher's Note: MDPI stays neutral with regard to jurisdictional claims in published maps and institutional affiliations.

Copyright: (C) 2022 by the authors. Licensee MDPI, Basel, Switzerland. This article is an open access article distributed under the terms and conditions of the Creative Commons Attribution (CC BY) license (https:/ / creativecommons.org/licenses/by/ $4.0 /)$.

\begin{abstract}
The exploitation and harnessing of renewable energies are becoming increasingly important throughout the world. This study presents a method of methane $\left(\mathrm{CH}_{4}\right)$ generation using biological disintegration of food waste (FW) by anaerobic digestion (AD). The $\mathrm{CH}_{4}$ production was enhanced by the addition of three different types of iron oxide $\left(\mathrm{Fe}_{3} \mathrm{O}_{4}\right)$ nanoparticles (NPs) (Cetyletrimethlebromide (CTAB), urea-capped $\mathrm{Fe}_{3} \mathrm{O}_{4} \mathrm{NPs}$ and $\mathrm{Fe}_{3} \mathrm{O}_{4}$ NPs without capping). The bio generation of $\mathrm{CH}_{4}$ and biodegradation of volatile solids (VS) were carried out in an AD treatment at mesophilic conditions $\left(35-37^{\circ} \mathrm{C}\right)$ for more than 50 days in batch mode. The concentration of all three types of NPs was kept constant at $75 \mathrm{mg} / \mathrm{L}$. It was noticed that urea-capped NPs produced the maximum $\mathrm{CH}_{4}$ (5.386 L), followed by $\mathrm{Fe}_{3} \mathrm{O}_{4} \mathrm{NPs}(5.212 \mathrm{~L})$. Methane production in the control bioreactor was $2.143 \mathrm{~L}$. The experimental results of $\mathrm{CH}_{4}$ generation (a dependent variable) were analyzed against the concentrations of NPs used (as independent variables) in multiple regression analysis (MRA). The overall model for the experiments resulted in $\mathrm{R}^{2}$ and R-adjusted values of 0.995 and 0.993 , respectively.
\end{abstract}

Keywords: anaerobic digestion; methane generation; multiple regression analysis; food waste

\section{Introduction}

Global warming and rapid urbanization have become big problems that must be talked about and managed. An increasing population and mass migration of people from rural to urban areas have added extra pressure to the energy demand in developed and developing nations [1]. On the other hand, in a report by the WWF, the burning of fossil fuels is reported as the primary contributor to global warming. With this in mind, renewable energy sources have been cited as the best alternative to decrease environmental pollution [2,3].

Alternative renewable energy sources include wind, solar, tidal, and biomass, and their use is planned to add energy production on a priority basis. The generation of biogas (which consists of $50-60 \%$ of methane with an upper calorific value of $6.0 \mathrm{KWh} / \mathrm{m}^{3}$ at standard temperature and pressure (STP)) is achieved from the oxygen-free bio-disintegration of biomass such as animal manure, crop residue, food waste, etc. [4,5]. Anaerobic digestion (AD) has been reported as a well-established and well-proven technology to treat organic waste $(\mathrm{OW})[6]$. AD treatment depends on multiple factors such as $\mathrm{pH}$, temperature, organic loading, supplements, and pretreatment types and extents. Nanotechnology has shown excellent compatibility and promising results in AD in recent years. In the literature, it is reported that the addition of nanoparticles (NPs) enhanced methane generation $\left(\mathrm{CH}_{4}\right)$ from $21.5 \%$ (size of NPs lies between 50 to $100 \mathrm{~nm}$ ) to greater than $150 \%$ by offering a greater surface area, a high reaction rate, and accelerated enzymatic activities $[7,8]$. 
Anaerobic digestion (AD) of organic matter (OM) has always been questioned due to the time-consuming bio-disintegration process. NPs have been called biodegradation accelerators due to their unique physicochemical properties. Therefore, urea-capped $\mathrm{Fe}_{3} \mathrm{O}_{4}$ nanoparticles (U- $\mathrm{Fe}_{3} \mathrm{O}_{4} \mathrm{NPs}$ ) are attractive materials for enhancing methane gas production by improving polycyclic aromatic hydrocarbons (PAHs) [9-11]. The mathematical demonstration of experimental results is as important as novel research. It enhances our understanding of physical processes by establishing models to design and upscale future lab work [12]. In this regard, Nweke et al. [13] and Nwabanne et al. [14] applied a first-order kinetic model to determine the substrate consumption rate. Furthermore, the Monod model and modified Gompertz model were reported to predict microbial or biomass growth and methane production, respectively [15-18]. Moreover, Sung and Liu conducted a linear regression analysis to describe ammonia inhibition in anaerobic digestion. In another study, multiple regression analysis (MRA) was applied to compare the biomethane potential (BMP) of various feedstocks $[19,20]$.

Hence, this study was designed to carry out a MRA of anaerobically produced methane in the presence of NPs. During the mathematical analysis, the cumulative $\mathrm{CH}_{4}$ production from the control bioreactor $\left(R_{c}\right)$ is established as the dependent variable and the bioreactors supplemented with NPs $\left(\mathrm{Fe}_{3} \mathrm{O}_{4}, \mathrm{CTAB}\right.$-capped, urea-capped) as the independent variables. This study provides data from a statistical analysis of the AD process when augmented with NPs.

\section{Materials and Methods}

\subsection{Materials and Chemicals}

Iron chloride tetra and hexahydrate (Fe-II and Fe-III) were used as fundamental salts to synthesize the NPs. The synthesis process was the same as in [8], the results of which have been published in our previous studies [4,18]. Non-homogeneous leftover food waste (FW) was used as a substrate and was collected from various on-campus locations.

\subsection{Substrate and Nanoparticles Preparation}

Before adding NPs to the bio digesters, the dried NPs were sonicated using a Sonicator (IK/UTSB/01), IMehran University, Jamshoro, Pakistan at $40{ }^{\circ} \mathrm{C}$ for $15 \mathrm{~min}$ to remove impurities and liquefy the NPs as shown in Figure 1. Then, the impurities were slowly removed from the surface.

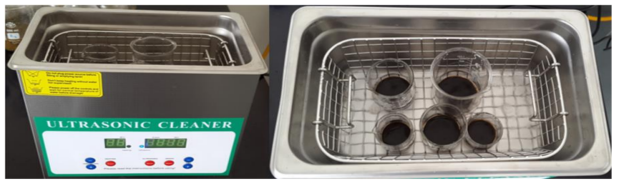

Figure 1. Removal of impurities from NPs by sonication.

The leftover FW contained various wastes, which included mainly cooked and some uncooked portions. Initially, the biodegradables were separated from the non-biodegradables manually. The size was reduced using a mechanical grinder as shown in Figure 2; thus, the homogeneity of the fractions was ensured.

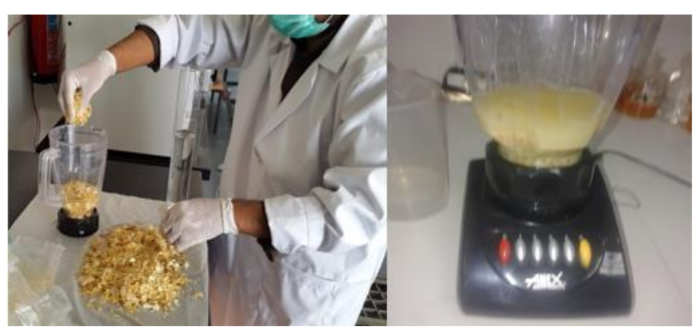

Figure 2. Preparation of substrate for anaerobic treatment. 


\subsection{Experimental Setup}

The AD of FW was set to mesophilic conditions $\left(35-37^{\circ} \mathrm{C}\right)$ in a batch mode for 50 days. We used $500 \mathrm{~mL}$ culture bottles as the bioreactors with a $300 \mathrm{~mL}$ working volume, as presented in Figure 3. Organic loading and NP concentration (except control, $R_{c}$ ) in each bioreactor were set to $6.653 \mathrm{gVS}$ and $75 \mathrm{mg} / \mathrm{L}$, respectively. The bioreactors were labeled $\mathrm{R}_{\mathrm{ct}}, \mathrm{R}_{\mathrm{u}}, \mathrm{Ri}, \mathrm{CTAB}$ capped loaded, urea added, and $\mathrm{Fe}_{3} \mathrm{O}_{4}$ supplemented.

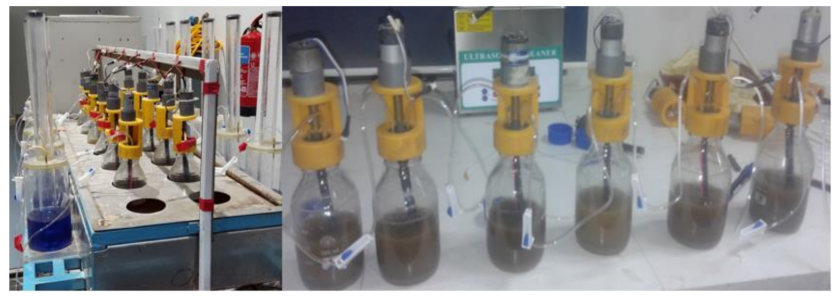

Figure 3. Lab scale batch mode anaerobic digester setup and bioreactors.

Each bioreactor was run in duplicate to improve the accuracy of the reading. Before the bioreactors were placed into the thermally coupled water bath, nitrogen gas $\left(\mathrm{N}_{2}\right)$ was used to purge the bioreactors for 5-10 min to confirm the anaerobic conditions. Furthermore, DC motors were installed for mixing the substrate for 30 s every $30 \mathrm{~min}$. An alkali solution of $5 \mathrm{M} \mathrm{NaOH}$ was used to measure $\mathrm{CH}_{4}$ by adsorbing the other gases, as reported in [21]. Note that methane generation was measured every day. All the pre-and post-parameters were analyzed during batch assays $[4,18,22]$.

\subsection{Regression Model}

This study aimed to find an equation that describes or summarizes the relationships in a set of data [23]. The data set is based on the impact of different types of NPs on methane generation and was studied using linear regression (single factor/variable) and multiple regression models (MRM) in MS Excel 2016 (Microsoft, Redmond, WA, USA). Kafle and Chen performed the analysis using an earlier version of MS Excel (2007) [20]. Furthermore, this model was created in order to analyze the straight-line relationships between the four variables. The general multiple regression estimates the $\hat{s}$ in the equation as [20]:

$$
Y=\kappa_{0}+\kappa_{1} X_{1}+\kappa_{2} X_{2}+\kappa_{3} X_{3}+\ldots+\kappa_{n} X_{n}
$$

where $X_{n}$ represents an independent variable (IV's) and $Y$ is the dependent variable. The is are the unknown regression coefficients. The significance of the results was determined by assuming a confidence interval $(\alpha=0.05)$ of $95 \%$.

\section{Results and Discussion}

\subsection{Nanoparticles vs. Methane Generation}

The impact of the addition of NPs was experimentally studied in the batch mode of $\mathrm{AD}$ of FW to enhance bio-methane generation. Figure 4 shows that the bioreactors loaded with NPs $\left(R_{\mathrm{u}}, \mathrm{R}_{\mathrm{ct}}\right.$, and $\left.\mathrm{R}_{\mathrm{i}}\right)$ exhibit high methane production. Abdelsalam et al. [8] reported a 1.6-fold enhancement of methane when $20 \mathrm{mg} / \mathrm{L}$ of $\mathrm{Fe}_{3} \mathrm{O}_{4} \mathrm{NPs}$ were added to bioreactors. In our study, $\mathrm{Fe}_{2} \mathrm{O}_{4}, \mathrm{CTAB}$, and urea-capped NPs enhanced $\mathrm{CH}_{4}$ generation by $1.45,1.14$, and 1.52 times at $75 \mathrm{mg} / \mathrm{L}$ concentration of NPs. Cumulatively, the methane production was $2.14 \mathrm{~L}, 4.584 \mathrm{~L}, 5.386 \mathrm{~L}$, and $5.255 \mathrm{~L}$ in $\mathrm{R}_{\mathrm{c}}, \mathrm{R}_{\mathrm{ct}}, \mathrm{R}_{\mathrm{u}}$, and $\mathrm{R}_{\mathrm{i}}$, respectively. Khalid et al. [24] observed a 129\% increase in methane yield while treating rice straw in the presence of magnetite and alkali pretreatment. Moreover, Zhang et al. [25] reported that methanogens, which are the prime bacteria involved in methane generation, could be improved by adding nano zero-valent iron NPs [26]. This difference in $\mathrm{CH}_{4}$ production might be caused by the composition of substrate irrespective of NP concentration. FW contains various components, and each component has its own biodegradability capacity. Apart from the bio methane increment, the addition of NPs increased biocompatibility and 
improved process stability. The effect of NPs on $\mathrm{pH}, \mathrm{VS}, \mathrm{TS}$, and other improvements in kinetics has been discussed and reported in our previous studies $[4,18]$. Furthermore, the supplementation of NPs expanded methane generation, accelerated the hydrolysis rate and reduced the lag phase.

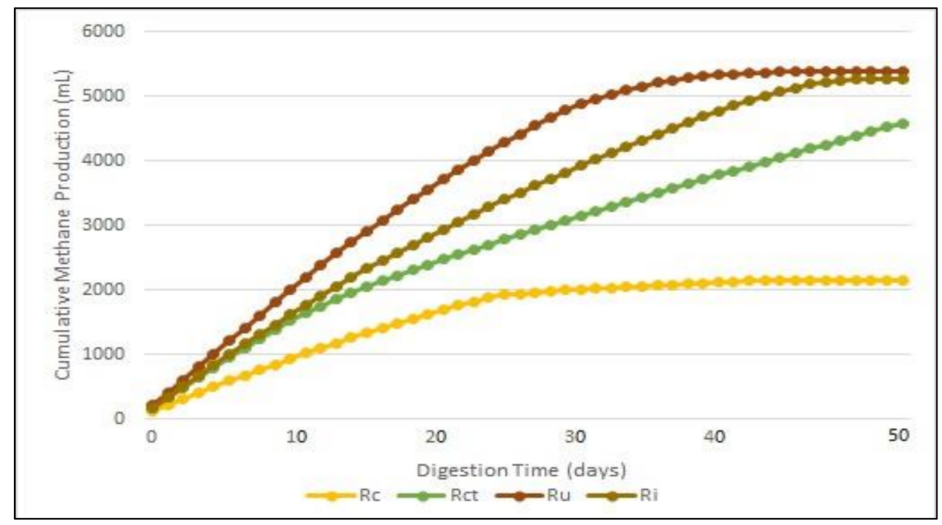

Figure 4. The impact of NPs on cumulative methane generation in $R_{u}, R_{i}$, and $R_{c t}$ bioreactors with respect to $R_{c}$ (control bioreactor).

The addition of NPs endured the highest removal of volatile and total solids, which reached more than $92 \%$ and $90 \%$, respectively [18]. Meanwhile, $20 \mathrm{mg} / \mathrm{L} \mathrm{of} \mathrm{Fe}_{3} \mathrm{O}_{4}$ achieved $74 \%$ removal [8]. The results of our study conflict with the findings of Abdelsalam, who used a two-stage system involving a thermophilic liquefaction reactor and a mesophilic anaerobic filter to convert over $95 \%$ of volatile solids to methane [27].

\subsection{Linear Regression Analysis (LRA)}

The impact of NP addition on cumulative $\mathrm{CH}_{4}$ generation was analyzed by considering single-variable data. Figure 5 illustrates the scattered nature of the linear model of experimentally generated $\mathrm{CH}_{4}$. In Figure $5 \mathrm{a}-\mathrm{d}$, the $\mathrm{R}^{2}$ lies in the range of 0.848 to 0.984 . This shows that the linear regression model fits well with the experimental data.

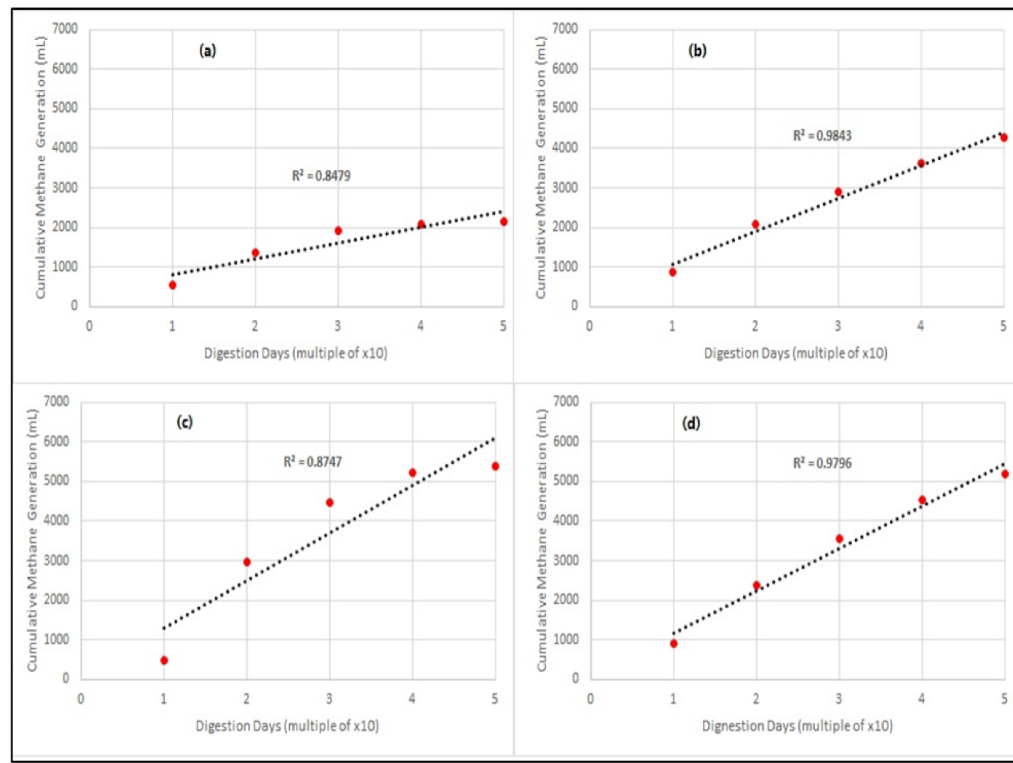

Figure 5. Simple linear regression plots; $(a) R_{c}$, (b) $R_{c t}$, (c) $R_{u}$, and (d) $R_{i}$.

\subsection{Multiple Regression Analysis (MAR)}

All four variables $\left(R_{c}, R_{c t}, R_{u}\right.$, and $\left.R_{i}\right)$ were considered together during our analysis. The effect of different variables has been studied in the literature $[28,29]$. The MAR fit 
the data well and produced a 0.993 coefficient of determination $\left(R^{2}\right)$. The R-adjusted was found to be 0.993 , but with the linear regression model $R^{2}$ was 0.848 to 0.984 (Table 1 ). The results in this study are closer to the effects of multiple regression analyses presented by [29]. More than $99 \%$ invariance in methane generation in the control bioreactor was observed by adding NPs to the bioreactors.

Table 1. Analysis of variance (ANOVA).

\begin{tabular}{ccccccc}
\hline Model & & Sum of Squares & df & Mean Square & F & Sig-F \\
\hline \multirow{2}{*}{1} & Regression & $19,412,872.36$ & 3 & $6,470,957.453$ & 3448.952147 & $0.00^{\text {a }}$ \\
& Residual & $86,305.64594$ & 46 & 1876.209694 & & \\
& Total & $19,499,178.01$ & 49 & & & \\
\hline
\end{tabular}

a Predictors: (constant), $\mathrm{CH}_{4}$ generation from $\mathrm{R}_{\mathrm{ct}}, \mathrm{R}_{\mathrm{u}}$, and $\mathrm{R}_{\mathrm{i}}$; Dependent variable: $\mathrm{CH}_{4}$ generation from $\mathrm{R}_{\mathrm{c}}$.

The details of this analysis in MS Excel 2016 are given in the Supplementary Materials at the end of this article. The experimental data show that the maximum production of $\mathrm{CH}_{4}$ was achieved at 50 days of digestion. The R-adjusted value also confirms that 50 days of digestion is sufficient to measure the methane potential. In Table 1, the Sig-F value, which is lower than $\alpha=0.05$, confirms that the methane production was significantly improved when NPs were added. The general multiple regression models developed based on the nonstandard coefficients is given in Equation (2):

$$
Y_{\mathrm{CH}_{4}}=44.485+0.384 R_{c t}+0.588 R_{u}-0.525 R_{i}
$$

where $Y_{C H 4}$ is the cumulative methane yield from $\boldsymbol{R}_{\boldsymbol{c}}$, which was set as a dependent variable. To test the validity of MRM, a global test must be used, which determines whether all the independent variables have regression coefficients equal to zero. The samples of regression coefficients correspond to the regressions as reported by [29,30]. In another study, the multiple regression model was estimated by considering three independent variables as given in Equation (3):

$$
G_{0}=-163.8+12.85 C P-13.06 L I G+7.85 A D F
$$

where $G_{0}$ is the methane potential, $C P$ is the crude protein, $L I G$ is lignin, and $A D F$ is acid detergent fiber. This model was found to be the best fit to predict the experimental results when $R^{2}$ and R-adjusted were both 0.999 . Therefore, the results of this study are entirely in agreement with the results of [20]. The summary of the complete regression analysis is given in the Supplementary Materials (Table S1).

\section{Conclusions}

The addition of NPs to AD boosted methane generation significantly with good process compatibility. Three of the performance indicators, namely the methane generation from $R_{c t}, R_{u}$, and $R_{i}$, are significant predictors of the dependent variable $\mathrm{CH}_{4}$ production from $R_{c}$. Our regression analysis showed that the multiple regression model (MRM) best fits the experimental data rather than the single factor/variable regression model. The R2 and R-adjusted coefficients of the MRM were found to be good. Thus, we mathematically demonstrated that adding NPs significantly improved $\mathrm{CH}_{4}$ generation.

Supplementary Materials: The following are available online at https:/ /www.mdpi.com/article/ 10.3390/agriengineering4010009/s1, Figure S1: Data for regression analysis, Table S1: Data in trend format for regression analysis.

Author Contributions: Conceptualization, A.A. and H.A.K.; methodology, S.P.; software, A.A. and M.Z.A.; validation, A.A. and S.P.; formal analysis, H.A.K.; investigation, H.A.K.; resources, A.A.; data curation, A.A.; writing — original draft preparation, A.A.; writing — review and editing, H.A.K. and S.P.; funding acquisition, self-funding by all four authors (A.A., H.A.K., S.P. and M.Z.A.). All authors have read and agreed to the published version of the manuscript. 
Funding: Self-funded.

Institutional Review Board Statement: Not applicable.

Informed Consent Statement: Not applicable.

Data Availability Statement: Not applicable.

Conflicts of Interest: The authors declare no conflict of interest.

\section{References}

1. Ali, A.; Mahar, R.B.; Sheerazi, S.T.H. Renewable Electricity Generation from Food Waste through Anaerobic Digestion in Pakistan: A Mini-Review. Earth Syst. Environ. 2019, 3, 95-100. [CrossRef]

2. Panwar, N.L.; Kaushik, S.C.; Kothari, S. Role of renewable energy sources in environmental protection: A review. Renew. Sustain. Energy Rev. 2011, 15, 1513-1524. [CrossRef]

3. Dincer, I.; Midilli, A.; Hepbasli, A.; Karakoc, T.H. (Eds.) Global Warming: Engineering Solutions; Springer Science \& Business Media: Oshawa, CA, USA, 2009.

4. Ali, A.; Mahar, R.B.; Soomro, R.A.; Sherazi, S.T.H. Fe3O4 nanoparticles facilitated anaerobic digestion of organic fraction of municipal solid waste for enhancement of methane production. Energy Sources Part A Recovery Util. Environ. Eff. 2017, 39, 1815-1822. [CrossRef]

5. Baek, G.; Kim, J.; Kim, J.; Lee, C. Role and potential of direct interspecies electron transfer in anaerobic digestion. Energies 2018, 11, 107. [CrossRef]

6. Salminen, E.A.; Rintala, J.A. Semi-continuous anaerobic digestion of solid poultry slaughterhouse waste: Effect of hydraulic retention time and loading. Water Res. 2002, 36, 3175-3182. [CrossRef]

7. Ye, Q.; Zhang, Z.; Huang, Y.; Fang, T.; Cui, Q.; He, C.; Wang, H. Enhancing electron transfer by magnetite during phenanthrene anaerobic methanogenic degradation. Int. Biodeterior. Biodegrad. 2018, 129, 109-116. [CrossRef]

8. Abdelsalam, E.; Samer, M.; Attia, Y.A.; Abdel-Hadi, M.A.; Hassan, H.E.; Badr, Y. Influence of zero valent iron nanoparticles and magnetic iron oxide nanoparticles on biogas and methane production from anaerobic digestion of manure. Energy 2017, 120, 842-853. [CrossRef]

9. Gong, L.; Yang, X.; You, X.; Wang, J.; Zhou, J.; Zhou, Y.; Yang, J. Explore the effect of Fe3O4 nanoparticles (NPs) on anaerobic digestion of sludge. Environ. Technol. 2020, 11, 4093-4107. [CrossRef]

10. Panhwar, S.; Aftab, A.; Keerio, H.A.; Sarmadivaleh, M.; Tamer, U. A Novel Approach for Real-Time Enumeration of Escherichia coli ATCC 47076 in Water through High Multi-Functional Engineered Nano-Dispersible Electrode. J. Electrochem. Soc. 2021, 168, 037514. [CrossRef]

11. Panhwar, S.; Aftab, A.; Muqeet, M.; Keerio, H.A.; Solangi, G.S.; Suludere, Z.; Tamer, U. High-Performance E. coli AntibodyConjugated Gold Nanorods for the Selective Electrochemical Detection of Pathogens in Drinking Water. J. Electron. Mater. 2021, 50, 7119-7125. [CrossRef]

12. Ali, A.; Mahar, R.B.; Abdelsalam, E.M.; Sherazi, S.T.H. Kinetic Modeling for Bio augmented Anaerobic Digestion of the Organic Fraction of Municipal Solid Waste by Using Fe3O4 Nanoparticles. Waste Biomass Valorization 2018, 10, 1-12. [CrossRef]

13. Nweke, C.N.; Nwabanne, J.T.; Igbokwe, P.K. Kinetics of batch anaerobic digestion of vegetable oil wastewater. Open J. Water Pollut. Treat. 2014, 1, 1-10. [CrossRef]

14. Nwabanne, J.T.; Okoye, A.C.; Ezedinma, H.C. Kinetics of anaerobic digestion of palm oil mill effluent. Can. J. Pure Appl. Sci. 2012, $6,1877$.

15. Keerio, H.A.; Bae, W.; Park, J.; Kim, M. Substrate uptake, loss, and reserve in ammonia-oxidizing bacteria (AOB) under different substrate availabilities. Process Biochem. 2020, 91, 303-310. [CrossRef]

16. Keerio, H.A.; Bae, W. Experimental Investigation of Substrate Shock and Environmental Ammonium Concentration on the Stability of Ammonia-Oxidizing Bacteria (AOB). Water 2020, 12, 223. [CrossRef]

17. Jeyaseelan, S. A simple mathematical model for anaerobic digestion process. Water Sci. Technol. 1997, 35, 185-191. [CrossRef]

18. Ali, A.; Mahar, R.B.; Sherazi, S.T.H. Methane Augmentation of Anaerobic Digestion of Food Waste in the Presence of $\mathrm{Fe}_{3} \mathrm{O}_{4}$ and Carbamide Capped $\mathrm{Fe}_{3} \mathrm{O}_{4}$ Nanoparticles. Waste Biomass Valorization 2019, 11, 1-15. [CrossRef]

19. Sung, S.; Liu, T. Ammonia inhibition on thermophilic anaerobic digestion. Chemosphere 2003, 53, 43-52. [CrossRef]

20. Kafle, G.K.; Chen, L. Comparison on batch anaerobic digestion of five different livestock manures and prediction of biochemical methane potential (BMP) using different statistical models. Waste Manag. 2016, 48, 492-502. [CrossRef] [PubMed]

21. Ariunbaatar, J.; Panico, A.; Esposito, G.; Pirozzi, F.; Lens, P.N. Pretreatment methods to enhance anaerobic digestion of organic solid waste. Appl. Energy 2014, 123, 143-156. [CrossRef]

22. APHA. Standard Methods for the Examination of Water and Wastewater, 20th ed.; American Public Health Association (APHA): Washington, DC, USA, 1998.

23. Keerio, H.A.; Panhwar, S.; Shah, S.A.; Naji, A.M.; Ali, A.; Aftab, A. Investigation of Climate Change Variability under Climate Change Conditions over the Semi-Arid Region. J. Mech. Contin. Math. Sci. 2020, 15, 46-54. [CrossRef]

24. Khalid, M.J.; Waqas, A.; Nawaz, I. Synergistic effect of alkaline pretreatment and magnetite nanoparticle application on biogas production from rice straw. Bioresour. Technol. 2019, 275, 288-296. [CrossRef] [PubMed] 
25. Zhang, Y.; Feng, Y.; Quan, X. Zero-valent iron enhanced methanogenic activity in anaerobic digestion of waste activated sludge after heat and alkali pretreatment. Waste Manag. 2015, 38, 297-302. [CrossRef] [PubMed]

26. Panhwar, S.; Sahito, A.R.; Solangi, G.S.; Mahar, R.B.; Lal, J. Methane production by anaerobic digestion of spent wash in continuous stirred tank reactor. Mehran Univ. Res. J. Eng. Technol. 2019, 38, 791-798. [CrossRef]

27. Bouallagui, H.; Touhami, Y.; Cheikh, R.B.; Hamdi, M. Bioreactor performance in anaerobic digestion of fruit and vegetable wastes. Process Biochem. 2005, 40, 989-995. [CrossRef]

28. Plotts, T. A Multiple Regression Analysis of Factors Concerning Superintendent Longevity and Continuity Relative to Student Achievement. Ph.D. Thesis, Seton Hall University, South Orange, NJ, USA, 2011.

29. Turóczy, Z.; Marian, L. Multiple regression analysis of performance indicators in the ceramic industry. Procedia Econ. Financ. 2012, 3, 509-514. [CrossRef]

30. Kulcsar, E. Multiple regression analysis of main economic indicators in tourism. Rev. Tur.-Stud. Cercet. Tur. 2009, 8, 59-64. 